\section{Benchmarking the Efficiency of Transplanting Plant Cuttings at Large Young Plant Greenhouse Operations}

\author{
Yai Ulrich Adegbola, Paul R. Fisher ${ }^{1}$, and Alan W. Hodges \\ University of Florida IFAS, Gainesville, FL 32611
} Additional index words. cost accounting, greenhouse, labor efficiency, lean manufacturing,
nursery, return on investment, rooted cuttings

\begin{abstract}
Transplanting of unrooted cuttings into trays filled with root substrate is an initial process in the production of rooted cuttings. There is potential for companies producing transplants to decrease production costs and increase profit margins by improving the labor efficiency of this process; however, benchmarking between firms is lacking. This study focused on benchmarking labor productivity for transplanting cuttings at young plant operations and identifying key factors that differentiate efficiency between businesses. Data were collected on the transplanting process of 14 U.S. young plant greenhouse companies during their peak production week in 2016. Companies surveyed included nine operations producing bedding plants (BPs) as the major type of transplant. The total weekly labor allocated to transplant cuttings averaged $2109 \pm 449$ hours (mean $\pm S E$ ) at a labor cost of $\$ 26,392 \pm \$ 5842$ to transplant $\mathbf{1 , 3 1 6 , 1 1 1} \pm \mathbf{2 7 3 , 3 7 7}$ cuttings, resulting in a labor cost of $\$ 0.023 \pm \$ 0.003$ per cutting. For steps within the process of assembling a transplanted tray of cuttings, receiving and handling unrooted cuttings was $3 \%$ of the total labor cost, filling trays with root substrate was $8 \%$, inserting cuttings into the root substrate was $70 \%$, supervising was $10 \%$, and moving assembled trays to the greenhouse bench was $8 \%$. The labor cost per cutting varied nearly 5 -fold between growers, from $\$ \mathbf{0 . 0 1 0}$ to $\$ \mathbf{\$ 0 . 0 4 9}$, indicating potential for improved efficiency in higher cost locations. Differences in the labor cost between firms resulted from factors including the plant type produced in each location, with greater handling and grading required for tissue culture and herbaceous perennials compared with BP cuttings, and differences in the hourly labor cost to the business which ranged from $\$ 9.23$ to $\$ 18.66$ between locations. Although other factors such as training, available labor pool, and lean manufacturing optimization were observed to affect labor efficiency at individual locations, it was not possible to quantify these effects using the survey approach taken. Benchmarked figures can be used to highlight opportunities to improve labor efficiency and decrease production costs, and to evaluate return on investment for alternative labor-saving approaches including robotic transplanting.
\end{abstract}

The U.S. floriculture industry is becoming increasingly consolidated and globalized. Although total floriculture production increased from $\$ 3.83$ billion (B) to $\$ 4.37 \mathrm{~B}$ in the United States between 2009 and 2015 (USDA, 2010, 2016), the number of producers in the top 15 states decreased from 6457 to 5913 during the same period. The top 10 global producers of ornamental plant cuttings produced more than 4 billion cuttings in 2014, and many operations were located in Africa and Latin America to exploit low labor costs for export to Europe and North America (Drotleff, 2014).

The production process in propagation greenhouses in Europe and North America

\footnotetext{
Received for publication 23 Mar. 2018. Accepted for publication 22 May 2018.

We thank the industry sponsors in the Floriculture Research Alliance (floriculturealliance.org) and USDA-ARS Floriculture and Nursery Research Initiative \#58-3607-8-725 for supporting this research. This study was conducted under IRB-02 guidelines.

${ }^{1}$ Corresponding author. E-mail: pfisher@ufl.edu.
}

includes inspecting and organizing unrooted cuttings (typically received from offshore locations that have lower labor costs for harvesting cuttings), filling trays with substrate, inserting cuttings into the substrate ("transplanting"), moving assembled trays with cuttings to the propagation area, growing the roots and shoots of cuttings, and shipping rooted cuttings to customers (Fig. 1). These large, multitiered companies require highly efficient processes, trained staff, and lean manufacturing processes to consistently produce high-quality plant products and remain competitive in an increasingly global market. Lean manufacturing is an approach that focuses on cost reduction by eliminating non-value-added activities (Abdulmalek and Rajgopal, 2006), which is relevant to the factory-like production of transplants in large-scale, specialized greenhouse facilities. Although there is limited labor-related information available for the greenhouse industry, $\approx 25.4 \%$ of all tasks in these large greenhouse operations have been estimated to be performed with some kind of mechanization or automation (Posadas, 2012).
With increasing competition in the greenhouse production of floriculture crops, it is becoming important for growers to increase production efficiency and minimize waste of resources including labor, production space, and materials (Fisher et al., 2016). As a result, benchmarking within and across greenhouse firms is a valuable tool to evaluate efficiency. Business benchmarking establishes specific measures for a business to compare performance with other similar businesses in the industry (Uva and Richards, 2002). Comparison of a business to industry benchmark performance can assist in evaluating company strengths and weaknesses to capitalize on its competitive advantages (Hall and Hodges, 2010).

The objectives of this project were to benchmark labor productivity of transplanting cuttings at young plant greenhouse operations and to identify key factors that differentiated between labor efficiency at surveyed firms. A survey was conducted with 14 young plant greenhouse operations, and data were collected on production cost in the peak season (the week when the most cuttings were transplanted) during 2016. The survey population was a subsample of the $\approx 109$ producers of annual bedding and garden plants with more than $\$ 100,000$ in sales in the 15 major floriculture-producing states in the United States (USDA, 2016).

\section{Materials and Methods}

Sample population. The labor cost of transplanting unrooted plant cuttings during the peak spring season was evaluated in 14 U.S. young plant greenhouse companies located in five states in the eastern and midwestern United States. Firms in the survey group, each with at least $\$ 1$ million (M) in annual sales, had collaborated in previous studies by the Floriculture Research Alliance (floriculturealliance.org), which includes six university and multiple industry partners, and were willing to share sensitive financial and labor data (Institutional Review Board approved). Three of these greenhouses were ranked among the 20 largest young plant growing operations in the United States by units prepared to sell in 2016, and seven were ranked among the 2017 top 100 greenhouse growers by the total square feet of environmentally controlled greenhouse space in the United States (Drotleff, 2016, 2017a). All 14 surveyed grower operations produced rooted cuttings from vegetative-propagated stock plants or tissue culture. The most numerous transplant type at nine of the operations was BPs; one produced foliage and edible crops from tissue culture, one produced chrysanthemum, one produced herbaceous perennials, one produced woody perennials, and one produced poinsettia (Table 2). Only two of the surveyed locations had the same business owner, whereas other businesses were independently owned.

The process of transplanting unrooted plant cuttings followed several steps in all greenhouse operations surveyed: 1) receiving, 


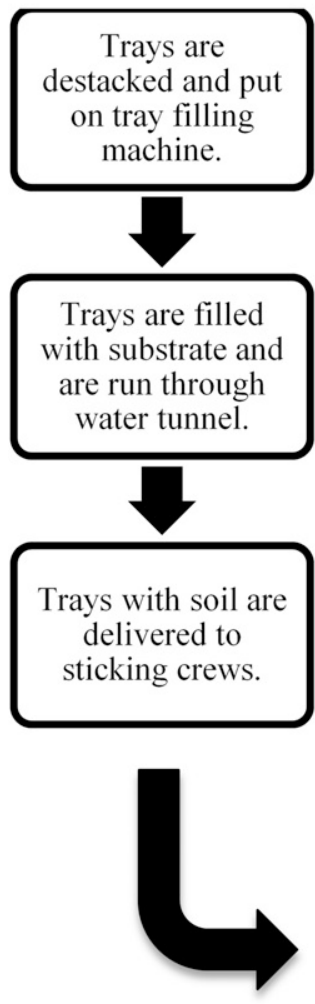

\section{Cuttings}

Cuttings are inspected, sorted and stored in a cooling chamber.
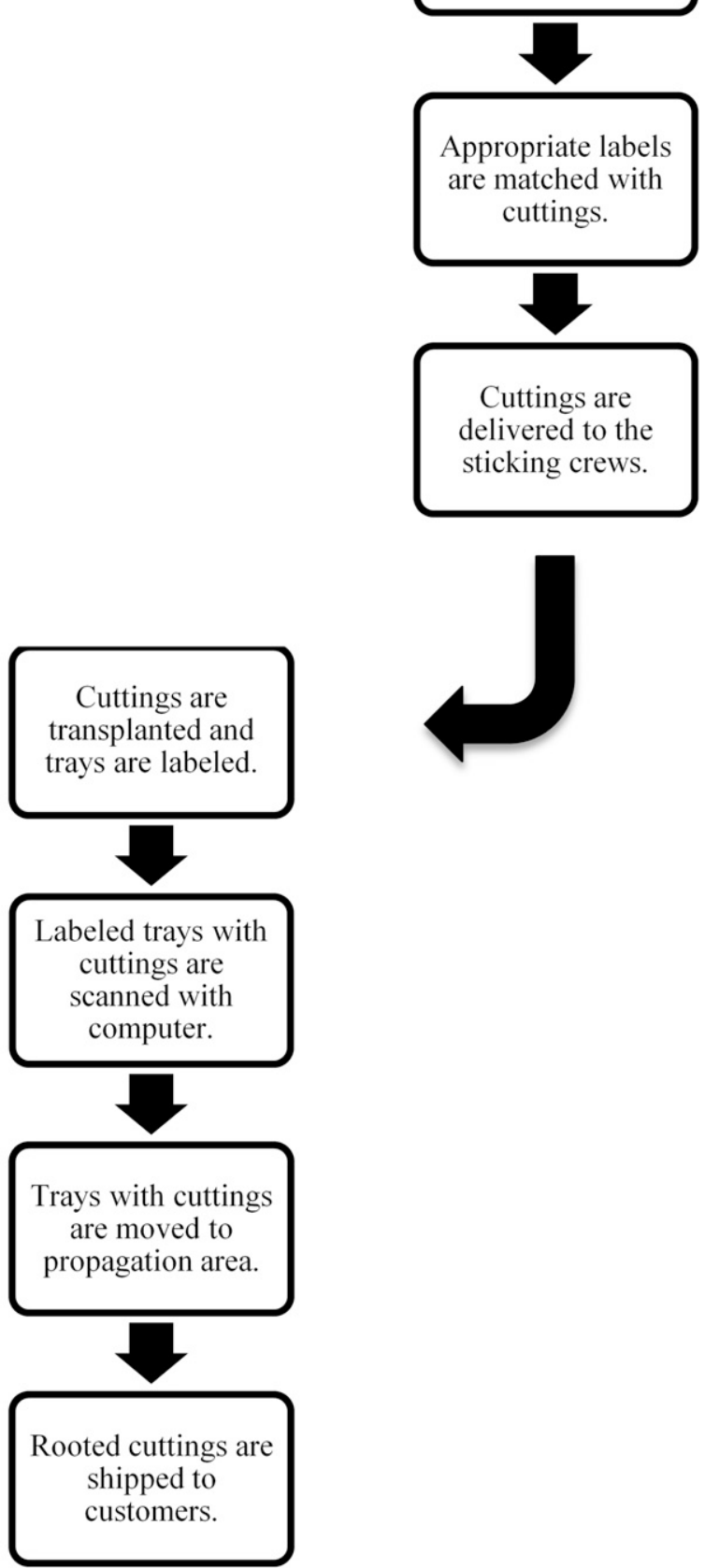

Fig. 1. The generalized process studied in the surveyed population of propagation greenhouses. This included inspecting and organizing unrooted cuttings, filling trays with substrate, transplanting cuttings into trays filled with substrate, and moving trays with cuttings to the greenhouse production area.

inspecting and organizing plants cuttings, 2) filling trays with substrate, 3 ) inserting plant cuttings into the root substrate, and 4) moving assembled trays with transplanted cuttings to the greenhouse for propagation. In two greenhouse locations (A \& N), plant cuttings were graded for size by the same workers on the transplant line before inserting into the tray, which increased the required labor time for step \#3. Two locations (D \& J) used trays that were prefilled with substrate by the tray supplier, which reduced their own labor cost for tray filling, but increased material cost. All growers surveyed had a manual transplanting process and all but one grower (D) used a conveyor belt to move trays with cuttings to the end of the transplanting line. Three growers used mobile greenhouse benches to move trays with cuttings to the propagation area, and other locations transported trays on rolling carts. Surveyed companies transplanted between 200,000 and $2.97 \mathrm{M}$ plant cuttings $(237,874$ to $2.97 \mathrm{M}$ for growers in the sample population who primarily produced BPs) in their peak week of 2016 (Table 2), resulting in a weekly labor cost of $\$ 6383$ $\$ 62,596$. The peak week varied between surveyed growers, but ranged from week 3 (end of January) to week 30 (mid-July). Computers recorded the number of cuttings transplanted by using a bar code pasted on each tray in all but one of the greenhouse operations surveyed. The bar code of each tray in most locations was scanned at the end of the transplanting line and contained information such as tray count, species, number of cuttings per cell, and transplant and ship date or week number.

Survey. A field survey was conducted at the 14 young plant greenhouse operations during a period of active crop production. Initial face-to-face structured interviews with greenhouse managers about the labor pool were conducted during the peak season of 2016, with site visits and follow-up phone interviews and e-mail communications for data verification in 2017 and 2018. Collected survey information included the demographics of the transplanting crews, training and selection procedures, pay schemes and incentives, and labor availability. Demographics collected of the transplanting crews included the percentage who were women, the percentage of new hires (not previously employed by the business) during the peak season, the percentage of workers seasonally employed, and the years of work experience at the business. Business owners were asked whether training was provided to seasonal workers beyond observing other experienced workers. Greenhouse operations were also asked to rate the availability of labor for transplanting on a scale of 1 to 5 , with 1 being extremely difficult and 5 being highly available. Data collected on the pay scheme and incentives consisted of the starting worker hourly wage, worker benefits, pay bonuses, overtime, and other incentives provided.

Labor efficiency. Labor time and cost for different processes of transplanting plant cuttings during a peak week were benchmarked for the 14 greenhouse operations. A spreadsheet costing model was developed to calculate aspects of labor efficiency in the sampled firms. This spreadsheet included the number of cuttings transplanted during a peak week, number of employees, hours worked, worker wages, and benefits, with Table 1 providing an example of data collected in one surveyed greenhouse location. In all 14 young plant greenhouse operations, labor requirements were calculated for the four steps of receiving and delivering cuttings, filling trays with substrate, transplanting cuttings into trays, and moving trays with cuttings to propagation. In addition, labor required to supervise workers (primarily on the transplanting line) was quantified separately because wage rate and provision of benefits were generally higher for supervisors. 
Labor costs including hourly wages and benefits were quantified for workers involved in each of the four steps of the transplanting process and were multiplied by the total worker hours during the peak week. The definition of "hourly wage" in this study included pay rate of individual worker plus bonuses, incentives, and overtime paid before federal or state income taxes. In two greenhouse operations, the hourly wage included bonus payments (piece rate) to workers for cuttings transplanted above a standard number of trays per hour previously established for each crop. This bonus was determined using a bar code with the employee identification. The code was pasted on each tray before or after the worker transplanted cuttings and was scanned at the end of the transplanting line. This allowed growers to track the number of cuttings and monitor performance quality of each worker. The hourly wage for seasonal employees at each surveyed location was compared against three economic indicators related to labor cost and availability, which were the hourly average farmworker and laborer wage rate, the adverse effect wage rate (which is a minimum hourly cost applied to companies using immigrant labor), and the local unemployment rate in the metropolitan area closest to firms surveyed.

The "hourly labor cost" to the greenhouse business was defined as the hourly wage plus benefits paid by the greenhouse operation including worker compensation insurance, health insurance, retirement, vacation and sick leave, holiday paid, and housing benefits. The hourly labor cost was used to calculate the cost of the transplanting process, which is useful for analyzing the feasibility and return on investment for laborsaving mechanization or automation.

\section{Results and Discussion}

The labor force for transplanting cuttings was characterized as mostly female, with marked seasonality of employment and a high rate of annual turnover. In 13 of the 14 operations, the proportion of women workers was $95 \%$ to $100 \%$ of the workers on the transplanting line, and in one case (location F), this was $50 \%$. Growers reported that women tended to transplant cuttings faster than men, and the fastest individual worker transplanting cuttings observed in each of the grower operations was female. Greenhouse work experience averaged $4.9 \pm 0.9$ years, and $26 \% \pm 4 \%$ of employees were new to transplanting cuttings during the 2016 season. With the highly seasonal spring peak in production of most growers, a large proportion $(52 \% \pm 9 \%)$ of employees transplanting cuttings were seasonally employed rather than being employed year-round. However, two of the smaller operations that did not primarily transplant spring BPs (locations A and C, Tables 2 and 3) did not employ seasonal staff.

When growers were asked "How difficult is labor availability for transplanting?" with

Table 1. Example of data collected from one greenhouse location on cuttings transplanted, labor cost, and time during their peak week of production in 2016. A total of 110 employees and 4,950 $\mathrm{h}$ were required to transplant $2,974,713$ cuttings during a peak week. With an average hourly labor cost of $\$ 12.55$ per hour, the labor cost of transplanting plant cuttings was $\$ 61,392$, the cost per cutting was $\$ 0.0206$, and the time per cutting was $6 \mathrm{~s}$.

\begin{tabular}{lcccccc}
\hline & $\begin{array}{c}\text { Number of } \\
\text { individual } \\
\text { workers }\end{array}$ & $\begin{array}{c}\text { Worker } \\
\text { (h/week) }\end{array}$ & $\begin{array}{c}\text { Hourly } \\
\text { labor } \\
\text { cost }\end{array}$ & $\begin{array}{c}\text { Labor } \\
\text { cost } \\
\text { per week }\end{array}$ & $\begin{array}{c}\text { Cost } \\
\text { per } \\
\text { cutting }\end{array}$ & $\begin{array}{c}\text { Seconds } \\
\text { per } \\
\text { cutting }\end{array}$ \\
Steps in the process & 11 & 495 & $\$ 11.47$ & $\$ 5,678$ & $\$ 0.0019$ & 0.6 \\
\hline $\begin{array}{l}\text { Receive, organize, and deliver } \\
\quad \text { cuttings to transplant line }\end{array}$ & & & & & & \\
Fill trays with substrate & 6 & 270 & $\$ 11.47$ & $\$ 3,097$ & $\$ 0.0010$ & 0.3 \\
Supervise transplant of cuttings & 7 & 315 & $\$ 16.80$ & $\$ 5,292$ & $\$ 0.0018$ & 0.4 \\
Transplant cuttings into trays & 75 & 3,375 & $\$ 12.34$ & $\$ 41,648$ & $\$ 0.0140$ & 4.1 \\
Move trays to greenhouse & 11 & 495 & $\$ 11.47$ & $\$ 5,678$ & $\$ 0.0019$ & 0.6 \\
Total process & 110 & 4,950 & - & $\$ 61,392$ & $\$ 0.0206$ & 6.0 \\
\hline
\end{tabular}

Table 2. Description of the 14 surveyed locations, including the "company code" used in other tables and figures, the main type of plant ("cutting type") transplanted during the peak week, the "peak week" when the maximum number of cuttings was transplanted, the number of cuttings transplanted during the peak week, and the "total hours" and "total labor cost" during the peak week for all transplant tasks (filling trays, receiving cuttings, supervising and transplanting cuttings, and delivering to the greenhouse).

\begin{tabular}{llrrrr}
\hline $\begin{array}{l}\text { Company } \\
\text { code }\end{array}$ & \multicolumn{1}{c}{ Cutting type } & $\begin{array}{c}\text { Peak }^{\mathrm{z}} \text { week } \\
\text { number }\end{array}$ & $\begin{array}{c}\text { Peak cutting } \\
\text { number }\end{array}$ & $\begin{array}{r}\text { Total } \\
\text { hours }\end{array}$ & $\begin{array}{r}\text { Total } \\
\text { labor cost }^{\mathrm{y}}\end{array}$ \\
\hline A & Tissue culture & $5-28^{\mathrm{x}}$ & 200,000 & 740 & $\$ 8,033$ \\
$\mathrm{~B}$ & Bedding & 3 & 864,248 & 1,128 & $\$ 10,427$ \\
$\mathrm{C}$ & Poinsettia & 30 & 513,261 & 663 & $\$ 6,383$ \\
D & Bedding & 6 & 585,311 & 934 & $\$ 12,793$ \\
E & Bedding & 5 & $2,809,632$ & 4,143 & $\$ 55,287$ \\
F & Bedding & 5 & $2,974,713$ & 4,950 & $\$ 61,392$ \\
G & Bedding & 6 & $2,408,900$ & 4,282 & $\$ 49,052$ \\
H & Bedding & 5 & $1,600,000$ & 1,464 & $\$ 16,596$ \\
I & Chrysanthemum & 20 & $1,664,002$ & 4,160 & $\$ 38,408$ \\
J & Bedding & 4 & 237,874 & 530 & $\$ 8,189$ \\
K & Bedding & 3 & 683,936 & 1,131 & $\$ 12,665$ \\
L & Bedding & 6 & $2,700,000$ & 3,624 & $\$ 62,596$ \\
M & Woody perennials & 14 & 778,000 & 704 & $\$ 7,702$ \\
N & Herbaceous perennials & 8 & 405,674 & 1,070 & $\$ 19,962$ \\
Average & & & $1,316,111$ & 2,109 & 26,392 \\
SE & & & 273,377 & 449 & 5,842 \\
\hline
\end{tabular}

${ }^{\mathrm{z}}$ The production week number using the International Organization for Standardization 8601 method.

${ }^{\mathrm{y}}$ Total labor cost to the business included wages, benefits, insurance, workers compensation, and labor taxes paid by the business.

${ }^{\mathrm{x}}$ This location reported that transplant numbers were fairly constant through weeks 5-28, without a clear seasonal peak.

a Likert scale (1: extremely difficult, 2: difficult, 3: neutral, 4: available and not a problem, and 5: highly available), the response averaged $2.8 \pm 0.2$, with four growers indicating that labor availability was " 2 : difficult." Seven of the 14 growers in the survey indicated that labor availability was " 3 : neutral," one grower indicated " 4 : available and not a problem," and no grower indicated " 5 : highly available." Labor availability is reportedly one of the top three concerns of growers in the United States, whereby 70 of the 100 largest greenhouse operations by covered production area in the U.S. growers reported to have been affected by labor shortage (Drotleff, 2017b). Low labor availability increases labor cost and the need for labor efficiency and automation. Four of the survey locations invested in automation of transplanting for a proportion of their plant cuttings within 1 year after this initial survey, which the growers mentioned in a follow-up informal interview were motivated primarily as a response to limited labor availability and secondarily to greater profitability.

Labor availability was likely to be limited because of the low wage level in most greenhouse operations and competition for workers from other industries. The hourly labor cost to the business was $\$ 12.49 \pm \$ 0.78$ (with a broad range from $\$ 9.23$ to $\$ 18.66$, which was more than $100 \%$ higher at the high-cost than the low-cost operations) (Table 3). The hourly wage for seasonal workers was $\$ 11.55 \pm \$ 0.49$ (range $\$ 9.00$ $\$ 13.53$ ). Most year-round employees received additional employee benefits beyond the required workers compensation. However, benefits were generally not provided to seasonal employees other than two greenhouses which provided paid holidays and vacation. Three growers automatically increased wages after a certain period of employment. The seasonal hourly wages from this survey can be compared against a national average of $\$ 13.51$ or $\$ 17.62$ for workers without or with a high school 
Table 3. Analysis of the type of employees and hourly labor cost of the 14 surveyed locations, and comparison against industry benchmarks. Survey data for the peak week of production included the total number of employees, the percentage of employees seasonally employed, the hourly labor cost to the business, and the average hourly wage paid to seasonal employees. Economic benchmarks for 2016 included the average hourly wage for farmworkers and laborers, the adverse effect wage rate, and the local unemployment rate in the regions where survey greenhouses were located.

\begin{tabular}{|c|c|c|c|c|c|c|c|}
\hline \multicolumn{5}{|c|}{ Survey data } & \multicolumn{3}{|c|}{$\begin{array}{l}\text { Economic benchmarks } \\
\end{array}$} \\
\hline $\begin{array}{l}\text { Company } \\
\text { code }\end{array}$ & $\begin{array}{l}\text { Total number } \\
\text { of employees }\end{array}$ & $\begin{array}{c}\text { Hourly } \\
\text { labor } \operatorname{cost}^{\mathrm{y}}\end{array}$ & $\begin{array}{c}\text { Seasonal } \\
\text { employees } \\
(\%)^{\mathrm{x}}\end{array}$ & $\begin{array}{l}\text { Avg hourly } \\
\text { seasonal } \\
\text { wagew }^{w}\end{array}$ & $\begin{array}{l}\text { Avg farmworkers } \\
\text { and laborers } \\
\text { hourly wage }^{v}\end{array}$ & $\begin{array}{c}\text { Adverse } \\
\text { effect } \\
\text { wage rate }^{\mathrm{u}}\end{array}$ & $\begin{array}{c}\text { Local area } \\
\text { unemployment } \\
\text { rates }^{\text {t }}(\%)\end{array}$ \\
\hline$\overline{\mathrm{A}}$ & 23 & $\$ 10.85$ & 0 & $\mathrm{~N} / \mathrm{A}$ & $\$ 10.38$ & $\$ 10.70$ & 4.5 \\
\hline B & 31 & $\$ 9.24$ & 44 & $\$ 9.06$ & $\$ 10.38$ & $\$ 10.70$ & 5 \\
\hline $\mathrm{C}$ & 14 & $\$ 9.63$ & 0 & N/A & $\$ 10.97$ & $\$ 10.72$ & 4.1 \\
\hline $\mathrm{D}$ & 37 & $\$ 13.69$ & 76 & $\$ 13.50$ & $\$ 13.75$ & $\$ 11.74$ & 2.7 \\
\hline $\mathrm{E}$ & 145 & $\$ 13.34$ & 72 & $\$ 12.45$ & $\$ 11.90$ & $\$ 12.02$ & 5.3 \\
\hline $\mathrm{F}$ & 110 & $\$ 12.55$ & 94 & $\$ 12.34$ & $\$ 11.90$ & $\$ 12.02$ & 3.4 \\
\hline G & 102 & $\$ 11.46$ & 21 & $\$ 11.00$ & $\$ 10.97$ & $\$ 10.72$ & 4.7 \\
\hline $\mathrm{H}$ & 38 & $\$ 11.34$ & 79 & $\$ 11.06$ & $\$ 13.75$ & $\$ 11.74$ & 2.7 \\
\hline I & 104 & $\$ 9.23$ & 94 & $\$ 9.00$ & $\$ 11.90$ & $\$ 12.02$ & 4.2 \\
\hline $\mathrm{J}$ & 37 & $\$ 15.45$ & 80 & $\$ 13.53$ & $\$ 12.44$ & $\$ 11.66$ & 5.3 \\
\hline K & 23 & $\$ 11.20$ & 10 & $\$ 9.65$ & $\$ 10.97$ & $\$ 10.72$ & 4.7 \\
\hline $\mathrm{L}$ & 74 & $\$ 17.27$ & 53 & $\$ 12.75$ & $\$ 12.43$ & $\$ 11.66$ & 5.1 \\
\hline M & 17 & $\$ 10.94$ & 60 & $\$ 10.77$ & $\$ 11.90$ & $\$ 12.02$ & 3.4 \\
\hline $\mathrm{N}$ & 87 & $\$ 18.66$ & 47 & $\$ 13.50$ & $\$ 11.90$ & $\$ 12.02$ & 3.4 \\
\hline Mean & 60 & $\$ 12.49$ & 52 & $\$ 11.55$ & $\$ 11.82$ & $\$ 11.46$ & 4.2 \\
\hline SE & 11 & $\$ 0.78$ & 9 & $\$ 0.49$ & $\$ 0.28$ & $\$ 0.16$ & 0.2 \\
\hline
\end{tabular}

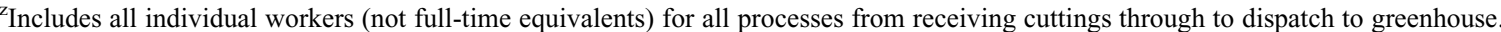

${ }^{\mathrm{y}}$ Total labor cost to the business divided by the number of hours worked.

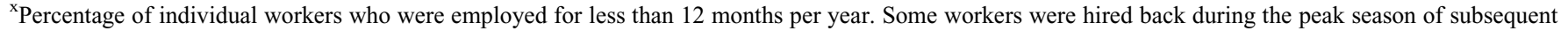
years.

${ }^{\mathrm{w}}$ Average hourly wage rate without benefits for individual seasonal employees in the transplanting crew plus bonuses, incentives, and overtime.

v 2016 average farmworkers and laborers hourly wage without benefits in the states where surveyed greenhouses were located according to the Bureau of Labor Statistics (USDOL, 2016b).

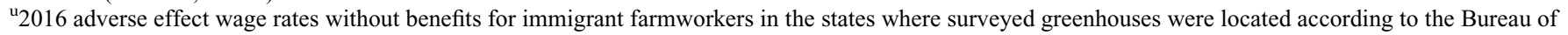
Labor Statistics (USDOL, 2016a).

t2016 unemployment rates for the metropolitan areas closest to surveyed location according to the Bureau of Labor Statistics (USDOL, 2016c).

$\mathrm{N} / \mathrm{A}=$ not applicable.

education, respectively (Economic Policy Institute, 2016). The average hourly wage for farmworkers and laborers during 2016 ranged between $\$ 10.38$ and $\$ 13.75$ in the regions where greenhouses surveyed were located (USDOL, 2016b). The surveyed hourly wages for seasonal workers are similar to a broader survey of U.S. greenhouse firms in 2016 (Zurko, 2016), whereby 43\% of companies surveyed paid their seasonal workers between $\$ 8.51$ and $\$ 10.00$ an hour and $32 \%$ paid between $\$ 10.01$ and $\$ 12.50$. Six locations paid seasonal workers below the adverse effect wage rates, which ranged between $\$ 10.70$ and $\$ 12.02$ during 2016 [Table 3, USDOL (2016a)]. Most of the locations surveyed did not use the $\mathrm{H}-2 \mathrm{~A}$ visa program for immigrant workers, but in follow-up informal interviews during 2017 and 2018, they indicated that several growers were either considering or initiating using that labor pool.

The large disparity in labor cost between locations was a response to factors such as the local unemployment rate, the reported availability of labor, the location of the greenhouse operations, and the proportion of year-round vs. seasonal staff (Table 3). Local unemployment rates were only $2.7 \%$ to $5.3 \%$ (Table 3). Gendreau (2015) considered that wages can vary by up to $35 \%$ for the same position across the United States because of local variations in supply and demand for labor, and in our survey, the highest cost operations paid $50 \%$ more than the lowest cost operations for seasonal workers. Growers mentioned during interviews that competition for greenhouse staff came from other sectors such as construction and manufacturing, and during warmer months, many seasonal workers moved to field operations on farms. Other factors not quantified in the study, such as local cost of living, may have contributed to wage rates.

The total number of employees involved in the transplanting process and the number of transplanted cuttings varied greatly between locations. The total number of fulltime equivalent (FTE) workers involved in the transplanting process ranged from 13 to 124 employees, averaging $53 \pm 11$ FTEs (530-4950 h/week), and the total number of workers from 14 to 145 employees. In most cases, growers with a high number of worker hours had two or three shifts. The number of cuttings transplanted during the peak week ranged from 200,000 to $2.97 \mathrm{M}$ (Table 2), averaging $1,316,111 \pm 273,377$. The subset of greenhouse operations producing BP cuttings used $62 \pm 15$ FTEs to transplant between 237,874 and $2.97 \mathrm{M}$ cuttings, averaging $1,651,624 \pm 362,454$ cuttings during the peak week. The correlation between peak week FTE employees and the number of cuttings transplanted in a peak week (Fig. 2A and B) may provide a useful industry benchmark for scheduling labor based on the projected number of cuttings.

Labor productivity to complete the process from receiving to delivering cuttings to the greenhouse averaged $6.43 \pm 0.73 \mathrm{~s}$ per cutting $(6 \pm 0.43 \mathrm{~s}$ per cutting for $\mathrm{BP})$ (Fig. 3B), which represented $560 \pm 353$ cuttings per hour $(681 \pm 61$ for BP). The transplanting task required most of this time: $897 \pm 90$ cuttings per hour (955 \pm 70 for BP) or $4.78 \pm 0.65 \mathrm{~s}$ per cutting $(3.92 \pm 0.27$ for BP). Across greenhouse locations, receiving and handling imported cuttings represented $3 \%$ of the total seconds per cutting, filling trays with substrate contributed $8 \%$, supervising was $7 \%$, transplanting cuttings into trays was $74 \%$, and moving cuttings to the greenhouse bench was $8 \%$ (Fig. 3B). The labor cost contributed by each task was similar to the time requirement, whereby transplanting cuttings into trays constituted an average $70 \%$ of the labor cost, supervising was $10 \%$, filling trays with substrate was $8 \%$, moving trays with cuttings for propagation was $8 \%$, and receiving cuttings was $3 \%$ (Fig. 3A). Therefore, the greatest potential to reduce the labor cost or maximize the return on investment in automation would focus on the transplanting task, rather than other tasks.

The wide range in labor productivity from 3.3 to $13.3 \mathrm{~s}$ per cutting (Fig. 3B), which represented 270-1105 cuttings per hour, was partly related to the major crop types transplanted during the peak week. Nine of the growers that produced BPs such as bacopa, calibrachoa, geranium, petunia, and lobelia (small cuttings generally planted in large batches) had a labor productivity from 3.3 to $8.02 \mathrm{~s}$ per cutting (449-1093 cuttings per hour). Major crops in the other five locations included chrysanthemum, poinsettia and woody shrub cuttings (large cuttings but with strong stems that are easy to insert into substrate), tissue culture plants (which tend 


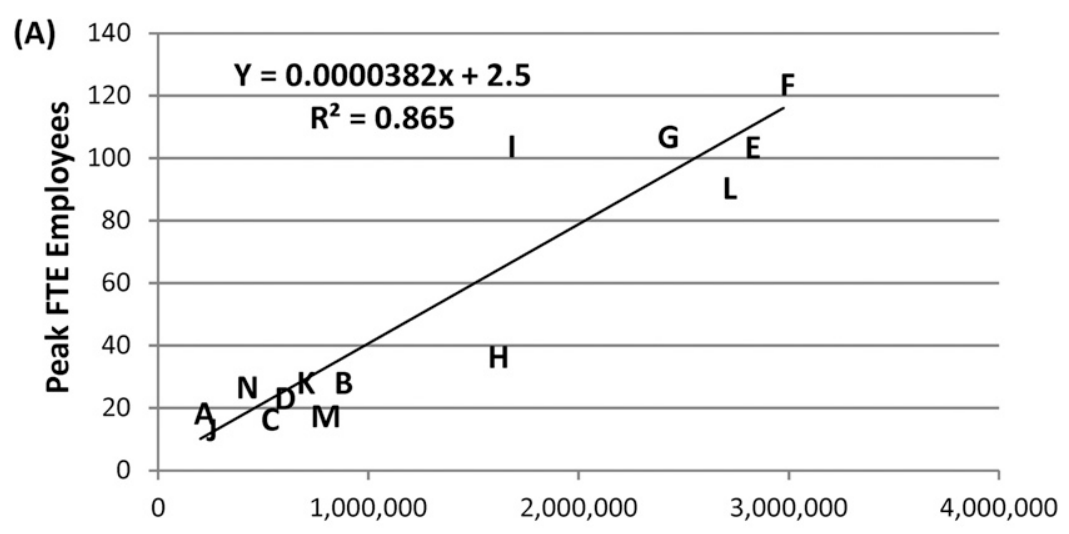

Number of Cuttings in a Peak Week for all Locations

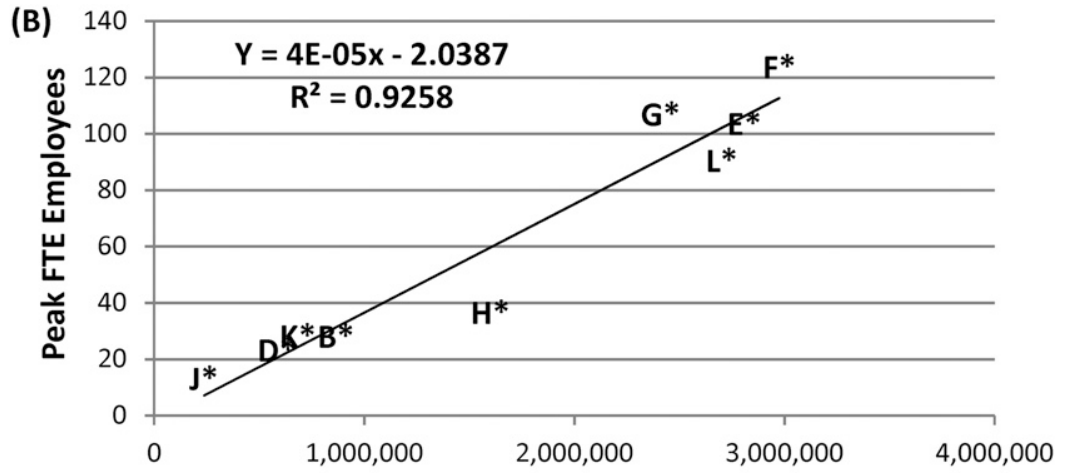

Number of Cuttings in a Peak Week for Locations that Transplanted Bedding Plants

Fig. 2. Number of full-time equivalent (FTE) employees vs. number of cuttings transplanted during a peak week for all locations (A) or only locations that primarily produced bedding plants (B). Letters for symbols represent the company codes listed in Table 2.

(A)

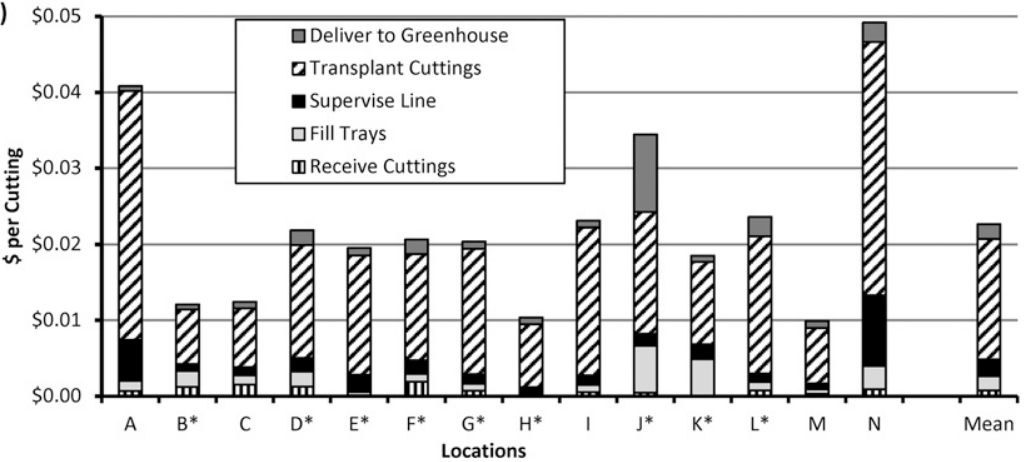

(B)

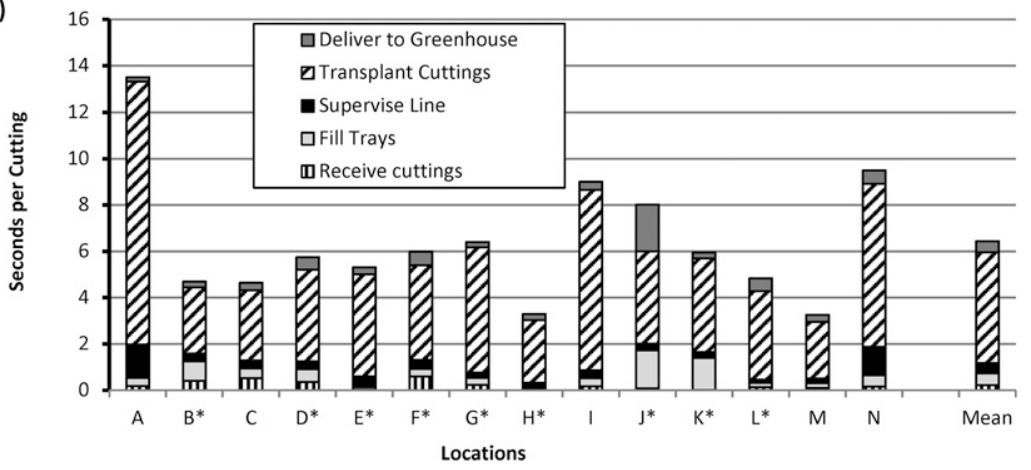

Fig. 3. Contribution of different tasks to (A) labor cost and (B) seconds per cutting at the surveyed locations. Locations with horizontal axis labels including the symbol (*) grew bedding plants as the major type of transplant. to be delicate and irregularly shaped), and herbaceous perennials (highly diverse size, often with few cuttings per cultivar) (Table 2). Location A required the highest time of $13.3 \mathrm{~s}$ per cutting and was the only grower in the sample population that primarily produced rooted cuttings from tissue culture. In addition to inserting cuttings, location A trimmed and divided plantlets as an extra part of the transplant process. Some tissue culture species are also delicate with a weak or nonexistent stem, which make them more difficult to handle than other plant cutting types. Locations that transplanted BPs varied by a factor of 2.4 between the fastest to the slowest operation (Fig. 3B), illustrating that plant type was not the only point of differentiation.

Employee training is a potential means to enhance labor productivity. For example, investment in training increased productivity by an average of $16 \%$ across manufacturing industries (Bartel, 1989). However, in our study, five operations provided no training to new employees beyond placing new workers with experienced workers to observe and learn practices. Standardized assembly line operations using lean flow principles are widely used to increase manufacturing efficiency by reducing non-value-added activities (Yarasi, 2011). However, although the task of placing cuttings into a tray is a repeated set of actions that could be optimized, only three greenhouses had a standardized method for placing plants into the trays and other locations allowed workers to transplant in the manner they chose. Although we could not quantify labor cost increases in companies without training or standardization of processes, these are potential areas for growers to increase labor productivity.

Greenhouses with a high labor cost per cutting, which ranged from $\$ 0.010$ to $\$ 0.049$ (\$0.010-\$0.034 for BP) (Fig. 4C) and averaged $\$ 0.023 \pm \$ 0.003$ (\$0.020 $\pm \$ 0.002$ for BP), had a combination of low time efficiency (transplanted fewer cuttings per hour), had a higher than average wage, or both. The cost per cutting increased as the time per cutting increased (Fig. 4B). There was no economy of scale relationship between labor cost per cutting and firm size (Fig. 4A). Although the three growers who transplanted the least number of cuttings all had a higher cost per cutting than average, smaller locations such as location $\mathrm{M}$ had a labor cost well below the average (Fig. 4A). Cost per cutting also increased as the hourly wage increased $(P<0.05)$; however, there was a great deal of variability in this relationship $\left(R^{2}=\right.$ $0.330)$. For example, location I with the lowest hourly labor cost of $\$ 9.23$ did not have the lowest cost per cutting (\$0.023) (Fig. 4C).

\section{Conclusion}

Benchmarking for the greenhouse industry can identify areas to focus on for improved production performance (Uva and Richards, 2002). Growers can use our results to compare against the labor efficiency of their own process of transplanting plant 
(A)

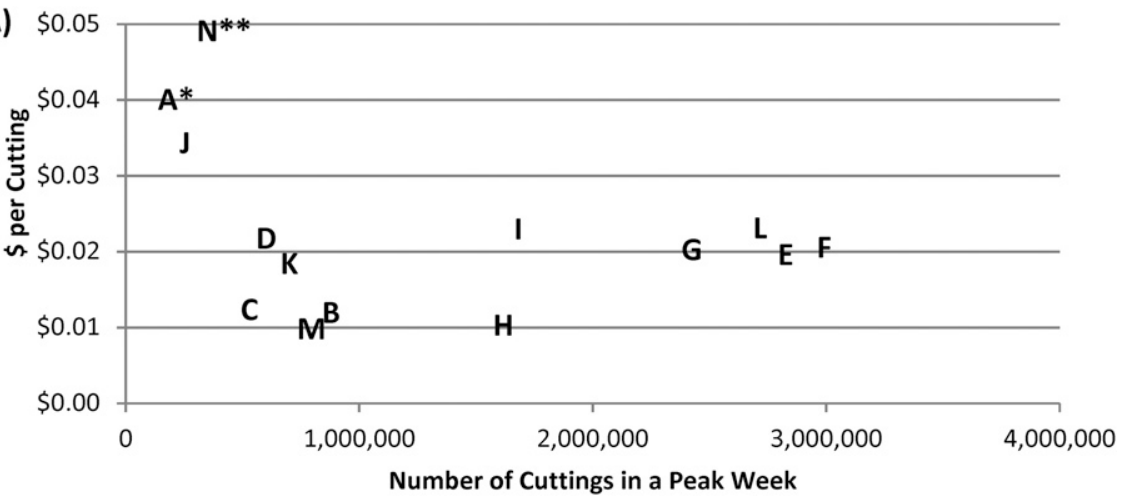

(B)

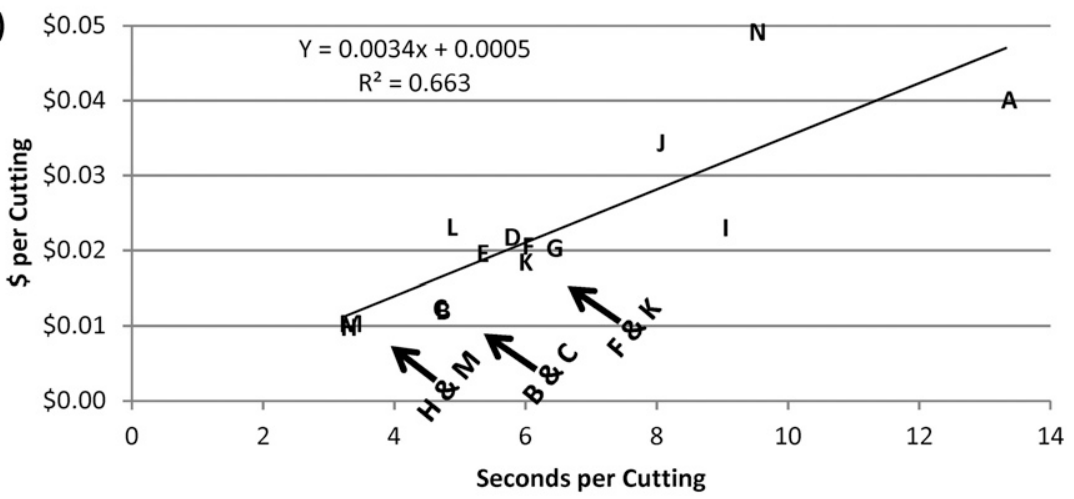

(C)

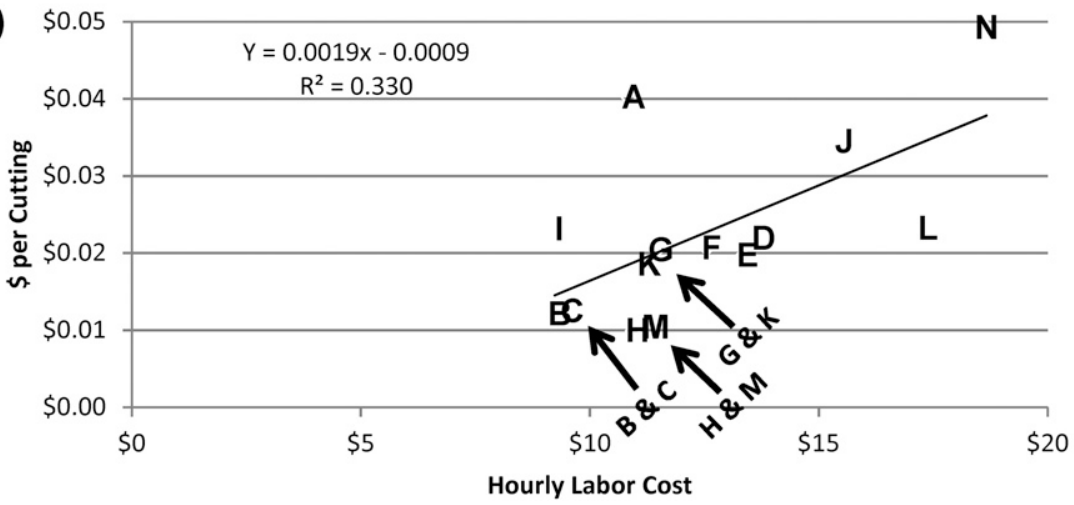

Fig. 4. (A) Relationship between the cost per cutting and the number of transplanted cuttings. In the two highest cost locations, location A (with symbol *) produced rooted cuttings from tissue culture and location $\mathrm{N}$ (with symbol ${ }^{* *}$ ) produced cuttings from herbaceous perennials as described in Table 2. (B) Relationship between the cost per cutting and time per cutting, and (C) the cost per cutting vs. the hourly labor cost. Letters for symbols represent the company codes listed in Table 2.

cuttings. This may help identify steps in the transplant process that are labor intensive compared with the survey group and the potential to decrease unit production cost and increase profit margin. Potential areas identified in this study to improve labor efficiency included increased training of new employees, standardizing of transplanting methods, and reducing labor time, especially for the task of transplanting cuttings into trays (which contributed an average $70 \%$ of labor cost). Grower concerns about limited labor availability increase the need for labor efficiency and automation. New automation technology is available for transplanting
Bartel, A. 1989. Formal employee training programs and their impact on labor productivity: Evidence from a human resource survey. National Bureau of Economic Research (Cambridge, MA) Working Paper No. 3026.

Drotleff, L. 2014. Top cuttings producers reveal offshore production is expanding. Greenhouse Grower. 8 Mar. 2018. <http:// www.greenhousegrower.com/management/topcuttings-producers-reveal-offshore-productionis-expanding/>.

Drotleff, L. 2016. The top young plant growers, and four critical challenges facing them. Greenhouse Grower. 8 Mar. 2018. <http://www. greenhousegrower.com/management/the-topyoung-plant-growers-and-four-critical-challengesfacing-them $/>$.

Drotleff, L. 2017a. 2017 greenhouse grower top 100 growers: The complete list, and more. Greenhouse Grower. 8 Mar. 2018. <http:// www.greenhousegrower.com/management/ 2017-greenhouse-grower-top-100-growers-thecomplete-list-and-more/>.

Drotleff, L. 2017b. The Top 100 growers are investing in more technology to offset labor shortages. Greenhouse Grower. 8 Mar. 2018. $<$ http://www.greenhousegrower.com/management/ the-top-100-growers-are-investing-in-moretechnology-to-offset-labor-shortages/>.

Economic Policy Institute. 2016. State of working America data library, wages by education. Washington, D.C. 25 June 2018. <https:// www.epi.org/data/\#cpsorg>.

Fisher, P.R., J.C. Vallejo, A.W. Hodges, and C. Hall. 2016. Tracking losses in floriculture crop production. Acta Hort. 1132:161-166.

Gendreau, K. 2015. Assessing a location's workforce. Global Consulting Group, Cushman \& Wakefield. 8 Mar. 2018. <http://www.areadevelopment.com/ labor-costs/workforce-q1-2015/assessing-alocations-labor-market-suitability-300836.shtml>.

Hall, C. and A.W. Hodges. 2010. Growers' increasing use of online benchmarking system. Assn. Hort. Professionals 922:9-10.

Posadas, B. 2012. Economic impacts of mechanization or automation on horticulture production firms sales, employment, and workers' earnings, safety, and retention. HortTechnology 22:388-401.

U.S. Department of Agriculture (USDA). 2010. Floriculture crops 2009 summary. National Agricultural Statistics Services Report, Washington, D.C.

U.S. Department of Agriculture. 2016. Floriculture crops 2015 summary. National Agricultural Statistics Services Report, Washington, D.C.

U.S. Department of Labor (USDOL). 2016a. 2016 adverse effect wage rates. Employment and Training Administration, Washington, D.C

U.S. Department of Labor. 2016b. Employment of farmworkers and laborers, crop, nursery, and greenhouse by state for 2016. Occupational Employment Statistics, Washington, D.C.

U.S. Department of Labor. 2016c. Unemployment rates for metropolitan areas for 2016, not seasonally adjusted. Local Area Unemployment Statistics. Washington, D.C.

Uva, W. and S. Richards. 2002. New York greenhouse business summary and financial analysis. Cornell University, Ithaca, NY.

Yarasi, P. 2011. Productivity improvement of a manual assembly line. Texas A\&M Univ., Texas, Master's Thesis.

Zurko, J. 2016. Wage \& benefit Survey; under the overtime rule. Grower Talks 80:70-72. 